\title{
Critical appraisal of tocilizumab in the treatment of moderate to severe rheumatoid arthritis
}

This article was published in the following Dove Press journal:

Journal of Blood Medicine

15 March 2010

Number of times this article has been viewed

\author{
Linda L Hushaw \\ Ray Sawaqed \\ Ghaleb Sweis \\ Jori Reigle \\ Anjali Gopal \\ Daniel Brandt \\ Nadia Sweis \\ James Curran \\ Timothy B Niewold \\ Nadera J Sweiss \\ University of Chicago, Section of \\ Rheumatology, Chicago, ILL, USA
}

Correspondence: Nadera J Sweiss University of Chicago, Section of Rheumatology, 5758 S. Maryland 4C. DCAM 4306, Chicago, ILL 60637-I470, USA Email nsweiss@medicine.bsd.uchicago.edu

\begin{abstract}
Recent advances in our understanding of the role of interleukin (IL)-6 in autoimmunity and in particular rheumatoid arthritis (RA) have brought about important changes in the way we think about autoimmune diseases. Encouraging data from several phase III clinical trials of tocilizumab, a humanized monoclonal antibody against IL-6R, have led to its approval in Europe for the treatment of moderate to severe RA. Data on clinical efficacy, patient-reported outcomes, safety, and cost-effectiveness with the use of tocilizumab in patients with RA will be summarized in this review, with particular emphasis on phase III clinical trials. Furthermore, adverse events associated with the use of tocilizumab will be reviewed. Future clinical trials will evaluate the role of tocilizumab in other autoimmune diseases. The goal of this review is to describe the current understanding of the role of IL- 6 in mediating the inflammatory response in RA, as well as the role of tocilizumab in the treatment of RA and the evolving role of this agent in other autoimmune diseases.
\end{abstract}

Keywords: tocilizumab, rheumatoid arthritis, IL-6, methotrexate

\section{Introduction}

Rheumatoid arthritis (RA) is an autoimmune disease characterized by persistent synovitis and destruction of bone and cartilage in multiple joints. RA affects up to $1 \%$ of the population world wide and is more common in women. ${ }^{1,2}$ Conventional disease-modifying antirheumatic drugs (DMARDs) treatment options for moderate to severe RA include corticosteroids, azathioprine, methotrexate and leflunomide. ${ }^{3-5}$ Current Food and Drug Administration (FDA)-approved biologic therapies include the tumor necrosis factor (TNF) inhibitors infliximab, adalimumab, golimumab, certolizumab, and etanercept; interleukin (IL)-1 inhibitor anakinra; the selective modulator of T cell activation abatacept; and the chimeric auto CD20 B-cell depleting agent, rituximab. ${ }^{6}$

Tocilizumab is the first humanized IL-6 receptor-inhibiting monoclonal antibody. IL-6 is a cytokine that is involved in the inflammatory and immunologic responses characteristic of multiple autoimmune diseases. The levels of IL-6 and its soluble receptor (sIL-6ra) are elevated in many rheumatic diseases. ${ }^{7,8}$ and the overproduction of IL-6 is thought to play a role in the pathogenesis of RA. ${ }^{9}$ Encouraging data from several clinical trials have led to the approval of tocilizumab in Europe in combination with methotrexate (MTX) for the treatment of adult patients with moderate to severe active RA who has inadequate response from previous treatment with one or more disease-modifying antirheumatic drugs (DMARDs) or tumor necrosis factor inhibitors (TNF). It is approved in Europe for use as monotherapy in patients who are 
either intolerant of MTX or for whom continued treatment with MTX is contraindicated. ${ }^{10}$ Furthermore, tocilizumab has been used in case reports and case series for the treatment of Castleman's disease and systemic-onset juvenile idiopathic arthritis. It is approved for these indications in Japan.

Efficacy measurements of RA agents used in clinical trials generally involve the American College of Rheumatology 20\%, 50\% and 70\% improvement criteria (ACR20, ACR50, and ACR70). ACR20 responses are defined as $\geq 20 \%$ improvement in the tender and swollen joint counts as well as $\geq 20 \%$ improvement in three of the five other core set measures: swollen joint count, tender joint count, physician's assessment of disease activity, patient's assessment of disease activity, patient's assessment of pain, and patient's assessment of physical function, and levels of an acute-phase reactant. ${ }^{11}$

Here we will review the current understanding of the role of IL-6 in mediating the inflammatory response characteristic of RA, as well as the role of tocilizumab in the treatment of RA, particularly its efficacy (using ACR criteria) and tolerability in patients with RA, as demonstrated in clinical trials. Finally, we will describe the evolving role of tocilizumab as a targeted therapy in autoimmune diseases other than RA.

\section{RA pathogenesis}

RA is a chronic inflammatory disease defined by articular inflammation which results in joint destruction. ${ }^{1} \mathrm{RA}$ is thought to begin when the immune system acquires immunity to an unknown self antigen, and this anti-self immune response later diversifies and evolves into a chronic inflammatory process. ${ }^{12}$ This dysregulation of the immune system is evidenced by the presence of autoantibodies such as anti-cyclic citrullinated peptide and rheumatoid factor, both of which are present many years prior to the patient presenting with clinical symptoms. ${ }^{13,14}$ The pathogenesis of rheumatoid arthritis (RA) involves the release of proinflammatory mediators, including IL-6, from infiltrating lymphocytes and monocytes in the synovium. IL-6 likely promotes and sustains inflammation in the synovium by several different mechanisms.

IL-6 is a pleiotropic cytokine that has a broad spectrum of biologic activities. IL-6 was originally identified as a B-cell differentiation factor and is involved in the development of antibody-producing plasma B-cells. This is noteworthy because as noted above RA is characterized by the formation of particular autoantibodies.

IL-6 acts upon neutrophils, which are important in the acute inflammatory response in the synovium. Specifically,
IL-6 increases neutrophil adherence to fibroblasts and increases leukocyte recruitment causing inflammation. ${ }^{15,16}$ Infiltrating inflammatory cells such as monocytes and macrophages, as well as endothelial cells release IL-6, which contribute to neutrophil recruitment during acute inflammation in RA. ${ }^{17}$

Furthermore, IL-6 stimulates vascular endothelial cells, synovial fibroblasts and osteoclasts and may contribute to the joint destruction and osteoporosis associated with RA. IL-6 has been shown to increase osteoclasts recruitment in human and animal studies. Additionally, IL-6 can stimulate osteoclasts maturation and activation and synoviocyte proliferation, ${ }^{18}$ suggesting a role in bone reabsorption and synovial pannus formation. A number of in vitro studies support the idea that IL-6 plays a role in osteoclastogenesis. ${ }^{19-23}$ Finally, IL-6 depletes proteoglycans, which are a major component of articular cartilage. Thus IL-6 may contribute to joint destruction by a variety of processes, and it is not surprising that the amount of IL-6 present in the synovial fluid of RA patients correlates well with local joint measures of chronic synovitis and the severity of joint destruction in RA. ${ }^{19}$

IL-6 is a major cytokine inducer of acute phase response proteins, ${ }^{20}$ and it is known to be an endogenous pyrogen. 6 Thus, it seems likely that IL- 6 plays a role in the systemic and constitutional manifestations of RA. ${ }^{21,22}$ Finally, IL-6 and CRP are both associated with increased cardiovascular risk. ${ }^{23,24}$ While this association does not prove causation, this point is of particular interest given the increased burden of atherosclerotic disease observed in RA patients as compared to controls matched for known cardiovascular risk factors. Interestingly, elevations in serum IL-6 are associated with increased mortality in patients presenting with acute coronary syndrome, again suggesting the possibility that IL-6 plays a causal role in atherosclerotic disease. ${ }^{25}$

IL-6 is frequently elevated in the synovial fluid and serum in patients with RA, and elevations correlate well with disease activity and joint destruction. The large numbers of potential mechanisms by which IL-6 may mediate the systemic and articular manifestations of RA make it a logical target for treatment of the disease..$^{20-23}$

\section{Tocilizumab}

Tocilizumab is a humanized, anti-human (IL-6) receptor monoclonal antibody of the IgG1 subclass, which prevents IL-6 from binding to its receptor. ${ }^{26}$ Since it is humanized, it will most likely present lower risk of antibody production compared with murine or chimeric mouse-human antibodies. ${ }^{26}$

IL-6 signal transduction is mediated by membrane bound (mIL-6R) and soluble (SIL-6R) receptors. In cells expressing 
IL-6R on their cell surface, IL-6 binds to mIL-6R, and by associating with the gp130 protein transmits a signal into the cells. In addition, IL-6 can form an association with sIL-6R and transmit a signal through gp $130 .{ }^{27}$ Therefore, it is crucial to inhibit both mIL-6R and sIL-6R-mediated signaling to block IL-6 signaling. ${ }^{18}$ Tocilizumab is developed by grafting the complementarity determining regions of a mouse antihuman IL-6 receptor antibody onto human IgG1. ${ }^{28}$ Tocilizumab competes for both the membrane-bound (mIL-6R) and soluble (sIL-6R) forms of human IL-6 receptor, effectively blocking IL-6-mediated signal transmission in cells. ${ }^{18}$

An analysis of the pharmacokinetic properties of intravenous tocilizumab examined data obtained from 1793 patients with RA who were administered tocilizumab 4 or $8 \mathrm{mg} / \mathrm{kg}$ every 4 weeks for 24 weeks. ${ }^{11}$ The predicted steady-state area under the concentration-time curve (AUC) was 2.7 with 6.5 increase in tocilizumab $8 \mathrm{mg} / \mathrm{kg}$ as compared to $4 \mathrm{mg} / \mathrm{kg}$. ${ }^{11}$ Tocilizumab has a long half-life that is non-linear and concentration-dependent, which allows for administration every 4 weeks. ${ }^{26}$ Tocilizumab $8 \mathrm{mg} / \mathrm{kg}$ administered every 4 weeks intravenously over 1 hour, is the recommended dosage for adults with RA. ${ }^{11}$ Prior to initiating therapy with tocilizumab, patients should be screened for latent tuberculosis infections and any other active infection, as use is not recommended in this setting. ${ }^{11}$

Regular observation of hepatic functions, lipid profile, and neutrophil and platelet counts is advised. ${ }^{11}$ It is recommended to discontinue the medication if any of the following occur: alanine aminotransferase (ALT) or aspartate aminotransferase $($ AST) $>5$ times upper limit of normal, absolute neutrophil count $<0.5$ or decreased platelet count $\left(<50 \times 10^{3} / \mathrm{uL}\right){ }^{11}$

\section{Phase I clinical trials}

A phase I trial reported by Choy et al was conducted to determine safety and efficacy of tocilizumab in 45 patients that were placed in four different single dosage cohorts of $0.1,1,5$, and $10 \mathrm{mg} / \mathrm{kg}$ tocilizumab therapy or placebo. The percentage of patients achieving an ACR20, ACR50, or ACR70 response, or those achieving a Disease Activity Score (DAS) 28 of less than 2.6 was not significantly different for any of the studied cohorts except the $5 \mathrm{mg} / \mathrm{kg}$ tocilizumabtreated group, in which 55.6\% of patients achieved an ACR20 response. Adverse events reported were considered mild or moderate, and most events were common to both the tocilizumab and placebo-treated groups.

A phase I/II open-label multicenter randomized doubleblind placebo-controlled clinical trial was conducted and reported by Nishimoto in 2004. One hundred sixty-two patients were placed in either the tocilizumab or placebotreated group. The tocilizumab-treated group received either 4 or $8 \mathrm{mg} / \mathrm{kg}$ intravenously every 4 weeks. Thirty-one of the patients withdrew during the study. Interestingly, 25 of the patients who withdrew were members of the placebo group. Statistically significant differences were observed in this study, indicating that the ACR20, ACR50, ACR70, and DAS28 of less than 2.6 was achieved in a higher percentage of patients treated with tocilizumab than those treated with placebo.

\section{Phase II clinical trials}

CHARISMA (Chugai Humanized Anti-Human Recombinant Interleukin-6 Monoclonal Antibody), a multicenter randomized double-blind placebo-controlled trial, evaluated the safety and efficacy of tocilizumab in 359 patients with active RA and inadequate response to methotrexate. Stable methotrexate dosing was required for at least 4 weeks prior to enrollment and continued throughout the trial. Patients were randomized to receive tocilizumab at 2,4 , or $8 \mathrm{mg} / \mathrm{kg}$ as monotherapy; tocilizumab in combination with methotrexate; or methotrexate with placebo. An ACR20 response at week 16 was achieved by $61 \%$ and $63 \%$ of patients receiving monotherapy with $4 \mathrm{mg} / \mathrm{kg}$ and $8 \mathrm{mg} / \mathrm{kg}$ of tocilizumab, compared with $41 \%$ of patients receiving placebo plus MTX $(P$ $<0.05)$ The ACR50 and ACR70 was significantly improved with combination therapy of $8 \mathrm{mg} / \mathrm{kg}$ of tocilizumab plus methotrexate as compared to placebo plus methotrexate. ${ }^{29}$

The 34 patients that withdrew from CHARISMA due to adverse events experienced symptoms that were considered to be of mild to moderate intensity. Approximately $25 \%$ of the total adverse events reported were considered to be tocilizumab treatment-related. Laboratory abnormalities noted such as increased ALT and AST levels were considered treatment-related because of their characteristic rise and fall between treatments. These laboratory abnormalities did not cause the discontinuation of treatment. ${ }^{29}$

Other tocilizumab-related laboratory abnormalities documented in the CHARISMA study included blood lipids. Non-fasting total cholesterol, HDL, and triglycerides rose at the start of tocilizumab treatment and then returned and were maintained throughout the treatment portion of the study. Subjects that had increased lipid levels were mostly those with higher levels at study initiation. ${ }^{29}$

In the initial blinded study of tocilizumab monotherapy conducted by Nishimoto in Japan, 143 of 163 patients continued on in STREAM, an open-label, long-term study 
extension to determine the safety and efficacy of tocilizumab. STREAM is the first study evaluating the efficacy of longterm tocilizumab monotherapy ( $<5$ years) for patients with RA with an inadequate response to initial DMARD therapy. Of the original 163 patients, 143 continued to receive tocilizumab $8 \mathrm{mg} / \mathrm{kg}$ plus oral prednisone $(<8.0 \mathrm{mg} /$ day $)$ or NSAIDs. At 5 years, 84\%, 69.1\% and $43.6 \%$ of the patients achieved ACR20, ACR50, and ACR70 improvement respectively. After 5 years of tocilizumab treatment, $89 \%$ of patients were taking a lower dose of corticosteroids. ${ }^{26}$ In the STREAM study, there were 49 withdrawals were due to adverse events. These adverse events were of mild or moderate severity. Only 1 of the 49 withdrawals from the STREAM study was due to inadequate response to tocilizumab, and the rate of serious infections was similar to that reported by studies of anti-TNF agents. ${ }^{26}$ Although CHARISMA and STREAM did not report any serious cardiovascular adverse events or increased risk of developing cardiovascular disorders, further studies will need to examine this potential given the increase in serum lipids commonly induced by tocilizumab. ${ }^{26,29}$

\section{Phase III clinical trials}

Results from the LITHE (TociLIzumab Safety and The Prevention of Structural Joint Damage) trial, a three-arm, randomized, double-blind, placebo-controlled study were presented at the 2009 American College of Rheumatology (ACR) meeting. Enrolled patients were given methotrexate and were randomized to receive either tocilizumab 8 $\mathrm{mg} / \mathrm{kg}$, tocilizumab $4 \mathrm{mg} / \mathrm{kg}$, or placebo every four weeks. The main outcomes measured in the trial were the changes from baseline in Genant-modified Sharp score and the AUC in the Health Assessment Questionnaire Disability Index (HAQ-DI) after 52 weeks. ACR response rates also were measured. Tocilizumab significantly inhibited the progression of joint damage in patients with RA. Also, patients treated with tocilizumab $8 \mathrm{mg} / \mathrm{kg}$ plus methotrexate at 52 weeks, $56 \%, 36 \%$, and 20\% achieved ACR20, ACR50 and ACR70 respectively. No differences in the frequency of adverse events were found among the 3 treatment arms. The study included nearly 1200 patients from 137 sites in 15 countries, including the United States. ${ }^{30}$

SAMURAI (Study of Active Controlled Monotherapy Used for Rheumatoid Arthritis) was an open-label multicenter randomized placebo-controlled study. The radiographic benefit of tocilizumab monotherapy versus conventional DMARD therapy was the primary outcome assessed during this trial was measured through a blinded evaluation of radiographs from 302 Japanese patients with active RA for 5 years or less. Radiographs of hands and forefeet were evaluated using the van der Heijde modified Sharp method. Patients were assigned to receive either tocilizumab monotherapy of $8 \mathrm{mg} / \mathrm{kg}$ every 4 weeks or conventional DMARDs for 52 weeks. In the primary efficacy analysis, the tocilizumab group showed significantly less radiographic disease progression than those patients treated with conventional DMARDs. At week 52, the proportion of patients achieving an ACR20, ACR50, and ACR70 response was 78\%, 64\%, and 44\% respectively in the tocilizumab group, which was statistically superior compared to the proportions of responders in the DMARD group $(34 \%, 13 \%$ and $6 \%$ ACR20, 50 and 70 responses respectively). ${ }^{31}$

Most adverse events reported in the SAMURAI study were mild or moderate in severity, and the proportion of these mild to moderate adverse events in the tocilizumab-treated group was very similar to that observed in the DMARD group ( $89 \%$ for tocilizumab vs $82 \%$ for DMARD). The most common adverse events reported were nasopharyngitis, with a similar occurrence rate in both groups. Laboratory abnormalities were more common in the tocilizumab group (61\% of subjects) as compared to the DMARD group (31\% of subjects), with many of the excess tocilizumab events being related to total cholesterol, triglycerides, HDL and LDL. ${ }^{31}$ However, similar to the CHARISMA study, adverse cardiovascular events were not reported. ${ }^{29}$ Serious adverse events (AEs) occurred in similar proportions of patients in the tocilizumab (18\%) and DMARD (14\%) groups with $7.6 \%$ and $4.1 \%$ of patients reporting a serious infection, respectively. ${ }^{31}$

SATORI (Study of Active-controlled Tocilizumab monotherapy for Rheumatoid arthritis patients with inadequate response to methotrexate) studied the clinical efficacy of tocilizumab monotherapy in 125 patients with RA with inadequate response to low dose methotrexate. Patients were assigned to receive either tocilizumab $8 \mathrm{mg} / \mathrm{kg}$ every 4 weeks plus methotrexate placebo (tocilizumab group) or a tocilizumab placebo plus methotrexate $8 \mathrm{mg}$ /week for 24 weeks (control group). The tocilizumab group achieved 80\% ACR20 response compared to $25 \%$ in the control group at week 24 , indicating superiority of tocilizumab treatment $(P<0.001)$. The ACR50 response rate was 11\% in the control group and $49 \%$ in the tocilizumab group, and the ACR70 response rate was $6 \%$ and $29 \%$ in the control group and the tocilizumab groups respectively. ${ }^{32}$ Seven patients withdrew from the tocilizumab arm and 31 withdrew from the methotrexate groups. However, most of these withdrawals were not due to adverse events, and those adverse events reported were comparable 
between both treatment arms. In this study, tocilizumab monotherapy for 24 weeks significantly improved signs and symptoms and was well tolerated in patients who had active RA despite receiving methotrexate. ${ }^{32}$

OPTION (Tocilizumab Pivotal Trial in methotrexate inadequate responders), the first published randomized double-blind placebo-controlled trial was designed to study tocilizumab efficacy on patients who also took a stable background dose of methotrexate. It involved 623 adult patients with moderate to severe RA split into three groups who received either tocilizumab $8 \mathrm{mg} / \mathrm{kg}, 4 \mathrm{mg} / \mathrm{kg}$, or placebo in addition to stable pre-study methotrexate doses of 10 to $25 \mathrm{mg}$ /week (average dose $\sim 15 \mathrm{mg} /$ week). The primary efficacy endpoint, the proportion of patients with an ACR20 response, was achieved in 59\% of patients in the tocilizumab $8 \mathrm{mg} / \mathrm{kg}$ group and $48 \%$ in the $4 \mathrm{mg} / \mathrm{kg}$ group, as compared to $26 \%$ of the subjects who received placebo. ACR50 and ACR70 responses were also significantly more common in the tocilizumab $8 \mathrm{mg} / \mathrm{kg}$ group as compared to placebo ( $44 \%$ vs $11 \%$ and $22 \%$ vs $2 \%$ respectively). Patients taking either dose of tocilizumab also had greater improvements in HAQ-DI scoring of physical function from baseline, greater FACIT-Fatigue scores, and better improvements in physical and mental SF36 scores than those given a placebo. Despite the efficacy benefits provided by tocilizumab, more patients receiving tocilizumab than those given a placebo had at least one adverse event (69\% in the $8 \mathrm{mg} / \mathrm{kg}$ group, $71 \%$ in the $4 \mathrm{mg} / \mathrm{kg}$ group, and $63 \%$ in the placebo group), with serious infections or infestations being the most commonly reported serious adverse event occurring in 6 patients in the $8 \mathrm{mg} / \mathrm{kg}$ group, 3 in the $4 \mathrm{mg} / \mathrm{kg}$ group, and 2 in the placebo group. No increases in levels of total bilirubin or alkaline phosphatase levels were reported in OPTION; however tocilizumab treatment was temporarily stopped or discontinued in OPTION subjects that displayed extremely high ALT and AST levels. ${ }^{33}$

RADIATE (Rheumatoid arthritis study in Anti-TNF failures) involved 499 RA patients, and its basic study design was similar to that of OPTION. Patients were treated with a stable background dose of methotrexate of 10 to $25 \mathrm{mg}$ / week (average $\sim 16 \mathrm{mg} /$ week), and were split into the same three treatment groups. However, the patient population was limited to those who were previously refractory to anti-TNF therapy. An ACR20 response, which was the primary efficacy endpoint of the study, was achieved in $50 \%$ of the tocilizumab $8 \mathrm{mg} / \mathrm{kg}$ group, as compared to $30 \%$ in the $4 \mathrm{mg} / \mathrm{kg}$ group and $10 \%$ in the placebo group. As in the OPTION study, ACR50 and ACR70 responses were significantly more common in the tocilizumab $8 \mathrm{mg} / \mathrm{kg}$ group (29\% and 12\% respectively) as compared to the placebo group ( $4 \%$ and $1 \%$ respectively). ${ }^{34}$ Greater improvements in HAQ values from baseline were achieved by $8 \mathrm{mg} / \mathrm{kg}$ tocilizumab $(P<0.001)$ and $4 \mathrm{mg} / \mathrm{kg}$ tocilizumab $(P=0.003)$ relative to placebo. Mild and moderate cases of infection, gastrointestinal upset, rash, and headaches were frequently reported in both the tocilizumab-treated and placebo-control group in the RADIATE trial. Eighty-four percent and $87 \%$ of subjects experienced an adverse event in the $8 \mathrm{mg} / \mathrm{kg}$ and $4 \mathrm{mg} / \mathrm{kg}$ tocilizumab-treatment cohort respectively, which was similar to the $80 \%$ adverse event rate reported in the placebo-treated cohort. Five patients in the tocilizumab-treated group were diagnosed with Common Terminology Criteria for Adverse Events CTCAE grade 4 neutropenia, which caused withdrawal from the study. It was discovered that one the patients had grade 4 neutropenia prior to enrollment and treatment in the study; however the other 4 patients developed grade 4 neutropenia while on the study medication. $^{34}$

TOWARD (Tocilizumab in combination with traditional DMARD therapy) is the largest multicenter randomized double-blind placebo-controlled study to date, involving 1220 patients who were randomized in a $2: 1$ manner to receive either tocilizumab $8 \mathrm{mg} / \mathrm{kg}$ or placebo. Unlike the previous phase III trials, TOWARD was designed to study a more representative and diverse clinic population, as patients could be enrolled if they were taking any stable single or multiple agent conventional DMARD regimen, rather than just methotrexate. It did, however, exclude those who had had an inadequate response to anti-TNF therapy. Methotrexate was the most common background DMARD (average dose $\sim 15 \mathrm{mg} /$ week) and was used in approximately $76 \%$ of patients, followed by anti-malarials, sulfasalazine, and leflunomide were used in approximately $20 \%, 13 \%$, and $13 \%$ of patients respectively. Multiple DMARDs were used in 23\% of patients. Efficacy results for tocilizumab were similar to that of previous studies, with an ACR20 response rate (the primary endpoint) of $61 \%$, an ACR 50 of $38 \%$ and an ACR 70 of $21 \%$, all significantly increased as compared to placebo ACR20, ACR50 and ACR70 response rates of 25\%, 9\%, and $3 \%$ respectively. Tocilizumab was also superior to placebo in eliciting DAS28 and EULAR responses.

The TOWARD study noted a similar large number of mild and moderate severity adverse events, and some type of adverse event was reported in $73 \%$ of the tocilizumabtreated patients and $61 \%$ of the placebo-treated patients. Of the adverse events reported, less than $10 \%$ were serious and resulted in discontinuation of the trial, and the majority 
of these serious events occurred in the tocilizumab-treated group. Neutropenia was a common adverse event in the tocilizumab-treated group. The neutropenias reported were not clearly linked to any serious infections during the course of the trial, however as noted previously, the neutropenia observed can be profound in some cases.

The most recent study of tocilizumab in RA, AMBITION (Actemra versus Methotrexate double-blind investigative trial in monotherapy), involved a total of 673 patients and was a double-blind, double-dummy, parallel-group study that sought to compare tocilizumab $8 \mathrm{mg} / \mathrm{kg}$ as monotherapy compared to escalating doses of methotrexate in patients who had not previously failed methotrexate or biologics. For those who received methotrexate, the starting dose was $7.5 \mathrm{mg} /$ week and was quickly escalated to $20 \mathrm{mg} /$ week over an 8-week period. The primary endpoint, ACR20 response, was statistically superior in those who received tocilizumab monotherapy $(70 \%)$ compared to those in the methotrexate group $(52.5 \%)$. The proportion of patients who achieved a DAS28 $<2.6$ was also significantly higher in the tocilizumab monotherapy group (34\%) compared to the methotrexate group (12\%). There was no significant difference in the incidence of serious adverse events with tocilizumab versus methotrexate $(P=0.50)$ but in the tocilizumab group, there was a higher incidence of reversible grade 3 neutropenia $(3.1 \%$ vs $0.4 \%)$ and increased total cholesterol $>240 \mathrm{mg} / \mathrm{dL}$ (13.2\% vs $0.4 \%$ ) relative to placebo, respectively. ${ }^{35,36}$

\section{Summary of tocilizumab trials in RA}

The above trial data demonstrate the therapeutic efficacy of tocilizumab in adult patients $>18$ with active moderate-tosevere RA. Efficacy and safety results from the phase III trials are summarized in Table 1. The studies discussed in this review sought to assess the effects of treatment with intravenous tocilizumab at doses of 2 to $8 \mathrm{mg} / \mathrm{kg}$ every 4 weeks. ${ }^{37}$ ACR Response Criteria was used for efficacy analyses in all studies except the SAMURAI. Table 2 displays the adverse events and number of occurrences in published clinical trials of tocilizumab in RA. Those studies not included in the table did not have specific published adverse event data.

Overall, these trials demonstrated that tocilizumab was effective in RA treatment in a number of patient groups, including those with inadequate response to methotrexate or TNF inhibition. Tocilizumab in combination with methotrexate was quite effective in those who had failed anti-TNF therapy, and tocilizumab monotherapy was superior to methotrexate monotherapy in those who had not previously failed either drug. It is worth noting however, that only one large study (SAMURAI) lasting 52 weeks in 306 patients has examined the question of radiographic benefit from tocilizumab treatment. Radiographic progression occurred, but was retarded in those receiving tocilizumab monotherapy compared to conventional DMARDs in this randomized, blinded, but not placebo controlled study. Although direct comparisons between different studies is always fraught with difficulty due to different study designs and patient populations, the results seen in the large tocilizumab studies were similar to those obtained in recent RA trials of other biologic therapies, including rituximab in DANCER, ocrelizumab in ACTION, and certolizumab pegol in RAPID 2..$^{31,35,38,39}$

Tocilizumab monotherapy was generally well tolerated overall. There were no specific infections related to tocilizumab therapy, including tuberculosis, which is a concern with anti-TNF therapy. ${ }^{29,31,33-36}$ However, it is possible that a fatal reactivation of Epstein-Barr virus infection which occurred in a patient during a Japanese study may be attributed to tocilizumab. ${ }^{37}$ Moderate increases in serum levels of total cholesterol, triglycerides and high density lipoprotein cholesterol are common in tocilizumab recipients, as are elevations in serum transaminases. ${ }^{29,33-37}$ For example, in the SAMURAI study, laboratory abnormalities were almost twice as common in the tocilizumab group as compared to the DMARD group (61\% vs $31 \%$ of patients, respectively). ${ }^{31}$ As noted above, severe neutropenia has also been observed, and blood counts should be monitored regularly. Three malignancies were reported in SAMURAI in patients treated with tocilizumab. ${ }^{31}$ Additional analysis to compare the incidence of malignancies in Japanese RA patient will be required to assess the carcinogenic risk of IL-6 inhibition therapy.

\section{Future directions}

Tocilizumab has the potential of being used in various other autoimmune diseases which may be caused in part by dysregulation of IL-6. A case report described successful tocilizumab treatment of cardiomyopathy associated with Castleman disease, a rare lymphoproliferative disorder which is characterized by lymphadenopathy and inflammatory symptoms. IL-6 is thought to play a role in the pathogenesis of this disease, and the reversibility of cardiomyopathy following the use of tocilizumab in this case is intriguing. ${ }^{40}$

IL-6 may have prognostic significance in predicting cardiovascular events in patients with angiographically proven and clinically stable CAD. ${ }^{41}$ Additionally, IL-6 was found to be an independent and useful biomarker of atherosclerosis of 
Table I Summary of efficacy and safety results from phase III trials of tocilizumab

\begin{tabular}{|c|c|c|c|c|c|c|}
\hline Trial & $\mathbf{N}$ & Treatment arms & Main efficacy results & Other efficacy results & Safety outcomes & Duration \\
\hline LITHE $^{30}$ & 1196 & $\begin{array}{l}8 \mathrm{mg} / \mathrm{kg} \text { tocilizumab, } \\
4 \mathrm{mg} / \mathrm{kg} \text { tocilizumab, } \\
\text { or placebo once } \\
\text { every } 4 \text { weeks }\end{array}$ & $\begin{array}{l}\text { Tocilizumab significantly } \\
\text { inhibited progression of } \\
\text { joint damage }\end{array}$ & $\begin{array}{l}\text { With } 8 \mathrm{mg} / \mathrm{kg} \text { tocilizumab: } \\
\text { ACR20: } 56 \% \text {,ACR50: } 36 \% \\
\text { ACR70: } 20 \%\end{array}$ & $\begin{array}{l}\text { No differences in AEs among } \\
\text { treatment arms }\end{array}$ & 2 years \\
\hline SAMURAI $^{31}$ & 306 & $\begin{array}{l}8 \mathrm{mg} / \mathrm{kg} \text { tocilizumab } \\
\text { once every } 4 \text { weeks } \\
\text { or DMARDs }\end{array}$ & $\begin{array}{l}\text { Patients taking } \\
\text { tocilizumab had } \\
\text { significantly less } \\
\text { radiographic disease } \\
\text { progression than patients } \\
\text { treated with DMARDs }\end{array}$ & $\begin{array}{l}\text { Proportion of patients } \\
\text { achieving an ACR20, } \\
\text { ACR50, and ACR70 } \\
\text { response was statistically } \\
\text { superior to the DMARD } \\
\text { group and signs and } \\
\text { symptoms were more } \\
\text { improved in patients } \\
\text { receiving tocilizumab }\end{array}$ & $\begin{array}{l}\text { Similar proportions of mild } \\
\text { to moderate AEs ( } 89 \% \text { vs } \\
82 \% \text { ) and serious AEs ( } 18 \% \\
\text { vs I3\%) for tocilizumab and } \\
\text { DMARDs, respectively }\end{array}$ & 52 weeks \\
\hline SATORI ${ }^{32}$ & 125 & $\begin{array}{l}8 \mathrm{mg} / \mathrm{kg} \text { tocilizumab } \\
\text { every } 4 \text { weeks plus } \\
\text { MTX placebo } \\
\text { (tocilizumab group) } \\
\text { or tocilizumab placebo } \\
\text { plus MTX } 8 \mathrm{mg} / \text { week } \\
\text { (control group) }\end{array}$ & $\begin{array}{l}25.0 \% \text { and } 80.3 \% \text { of } \\
\text { patients in the control } \\
\text { and tocilizumabs groups } \\
\text { achieved ACR20, } \\
\text { respectively }\end{array}$ & $\begin{array}{l}\text { Tocilizumab significantly } \\
\text { decreased serum VEGF } \\
\text { levels }\end{array}$ & $\begin{array}{l}\text { Incidences of AEs were } 72 \% \\
\text { and } 92 \% \text { (serious AEs: } 4.7 \\
\text { and } 6.6 \% \text {; serious infections: } \\
\text { I.6 and } 3.3 \% \text { ) in control and } \\
\text { tocilizumab groups, } \\
\text { respectively; all serious AEs } \\
\text { improved with adequate } \\
\text { treatment }\end{array}$ & 24 weeks \\
\hline OPTION ${ }^{33}$ & 623 & $\begin{array}{l}8 \mathrm{mg} / \mathrm{kg} \text { tocilizumab, } \\
4 \mathrm{mg} / \mathrm{kg} \text { tocilizumab, or } \\
\text { placebo every } 4 \text { weeks } \\
\text { with MTX }\end{array}$ & $\begin{array}{l}\text { More ACR20 responses } \\
\text { in tocilizumab groups } \\
\text { than in placebo group } \\
\text { (odds ratio } 4.0 \text { [ } 95 \% \mathrm{Cl} \\
2.6-6 . \mathrm{I}], P<0.000 \mathrm{I} \text { for } \\
8 \mathrm{mg} / \mathrm{kg} \text { vs placebo; and } \\
2.6[\mathrm{I} .7-3.9], P<0.000 \mathrm{I} \\
\text { for } 4 \mathrm{mg} / \mathrm{kg} \text { vs placebo) }\end{array}$ & $\begin{array}{l}\text { Patients taking tocilizumab } \\
\text { had greater improvements } \\
\text { in HAQ-DI scoring of } \\
\text { physical function from } \\
\text { baseline, FACIT-Fatigue } \\
\text { scores, and physical and } \\
\text { mental SF36 scores than } \\
\text { those given a placebo }\end{array}$ & $\begin{array}{l}\text { More people in the } \\
\text { tocilizumab group had at } \\
\text { least I AE with the most } \\
\text { common serious AEs being } \\
\text { serious infections or } \\
\text { infestations } 6 \text { patients in } \\
8 \mathrm{mg} / \mathrm{kg} \text { group, } 3 \text { in the } 4 \mathrm{mg} / \mathrm{kg} \\
\text { group, and } 2 \text { in the placebo } \\
\text { group }\end{array}$ & 24 weeks \\
\hline RADIATE $^{34}$ & 499 & $\begin{array}{l}8 \mathrm{mg} / \mathrm{kg} \text { tocilizumab, } \\
4 \mathrm{mg} / \mathrm{kg} \text { tocilizumab, or } \\
\text { placebo every } 4 \text { weeks } \\
\text { with MTX }\end{array}$ & $\begin{array}{l}\text { ACR } 20 \text { was achieved in } \\
50 \% \text { of the tocilizumab } \\
8 \mathrm{mg} / \mathrm{kg} \text { group, as } \\
\text { compared to } 30 \% \text { in the } \\
4 \mathrm{mg} / \mathrm{kg} \text { group and } 10 \% \\
\text { in the placebo } \\
\text { group }\end{array}$ & $\begin{array}{l}\text { Greater improvements in } \\
\text { HAQ values from baseline } \\
\text { achieved by } 8 \mathrm{mg} / \mathrm{kg} \\
\text { tocilizumab }(P<0.00 \mathrm{I}) \\
\text { and } 4 \mathrm{mg} / \mathrm{kg} \text { tocilizumab } \\
(P=0.003) \text { relative to } \\
\text { placebo; DAS } 28 \text { and } \\
\text { EULAR responses also } \\
\text { were greater in tocilizumab } \\
\text { groups }\end{array}$ & $\begin{array}{l}\text { Mild and moderate cases of } \\
\text { infection, gastrointestinal } \\
\text { upset, rash, and headaches } \\
\text { were frequently reported in } \\
\text { both the tocilizumab-treated } \\
\text { and placebo-control group }\end{array}$ & 24 weeks \\
\hline TOWARD ${ }^{35}$ & 1220 & $\begin{array}{l}8 \mathrm{mg} / \mathrm{kg} \text { tocilizumab or } \\
\text { placebo every } 4 \text { weeks }\end{array}$ & $\begin{array}{l}\text { Significantly more ACR20 } \\
\text { responses achieved in the } \\
\text { tocilizumab plus DMARD } \\
\text { group than in the control } \\
\text { group }(61 \% \text { vs } 25 \% \text {; } \\
P<0.000 \text { I) }\end{array}$ & $\begin{array}{l}\text { Tocilizumab was superior } \\
\text { to placebo in DAS } 28 \text { and } \\
\text { EULAR responses }\end{array}$ & $\begin{array}{l}\text { AEs reported in } 73 \% \text { of the } \\
\text { tocilizumab-treated patients } \\
\text { and } 61 \% \text { of the placebo- } \\
\text { treated patients; majority of } \\
\text { serious AEs occurred in the } \\
\text { tocilizumab group }\end{array}$ & 24 weeks \\
\hline AMBITION ${ }^{36}$ & 673 & $\begin{array}{l}\text { Tocilizumab } 8 \mathrm{mg} / \mathrm{kg} \\
\text { monotherapy vs } \\
\text { escalating doses of } \\
\text { MTX }\end{array}$ & $\begin{array}{l}\text { ACR20 response, was } \\
\text { statistically superior in } \\
\text { those who received } \\
\text { tocilizumab monotherapy } \\
(70 \%) \text { compared to those } \\
\text { in the methotrexate } \\
\text { group }(52.5 \%)\end{array}$ & $\begin{array}{l}\text { DAS28 < } 2.6 \text { achieved by } \\
\text { significantly more patients } \\
\text { taking tocilizumab than } \\
\text { MTX ( } 34 \% \text { vs } 12 \%)\end{array}$ & $\begin{array}{l}\text { No differences in the } \\
\text { incidence of } A E s \text { between } \\
\text { tocilizumab and placebo } \\
\text { groups; most common } A E \\
\text { was infection }\end{array}$ & 24 weeks \\
\hline
\end{tabular}

Abbreviations: MTX, methotrexate;AEs, adverse events; DMARDs, disease-modifying antirheumatic drugs; HAQ, Health Assessment Questionnaire; DAS28, Disease Activity Scale in 28 Joints; EULAR, European League Against Rheumatism Responses;VEGF, vascular endothelial growth factor. 
Table 2 Adverse events and number of occurrences in published clinical trials of tocilizumab in rheumatoid arthritis

\begin{tabular}{|c|c|c|c|c|c|c|c|}
\hline & \multirow[t]{2}{*}{ Nishimoto $^{37}$} & \multirow{2}{*}{$\begin{array}{l}\text { Smolen }^{45} \\
\text { CHARISMA }\end{array}$} & \multicolumn{2}{|c|}{ Nishimoto ${ }^{31}$ SAMURAI } & \multicolumn{3}{|c|}{ Smolen ${ }^{33}$ OPTION } \\
\hline & & & $\begin{array}{l}\text { Tocilizumab } \\
8 \mathrm{mg} / \mathrm{kg}\end{array}$ & $\begin{array}{l}\text { Conventional } \\
\text { DMARDS }\end{array}$ & $\begin{array}{l}\text { Tocilizumab } \\
4 \mathrm{mg} / \mathrm{kg}\end{array}$ & $\begin{array}{l}\text { Tocilizumab } \\
8 \mathrm{mg} / \mathbf{k g}\end{array}$ & Placebo \\
\hline $\begin{array}{l}\text { Total number } \\
\text { of patients }\end{array}$ & 109 & 359 & 157 & 145 & 212 & 206 & 129 \\
\hline Nasopharyngitis & & 23 & 56 & 47 & 11 & 12 & 10 \\
\hline Rash & & 24 & 17 & 6 & 13 & II & 3 \\
\hline Fever & 6 & 3 & & & & & \\
\hline Headache & 5 & 29 & II & 3 & 15 & 14 & 9 \\
\hline Increased blood pressure & 3 & 15 & & & 7 & 8 & 9 \\
\hline Infusion reaction & 16 & & 11 & & & & \\
\hline Pruritis & 5 & & 9 & 2 & & & \\
\hline Sleepiness & 3 & & & & & & \\
\hline Stomatitis & 7 & 9 & 9 & 13 & & & \\
\hline Upper respiratory infection & 14 & 29 & & & 12 & 17 & 13 \\
\hline Cough & & 10 & & & 7 & 3 & 3 \\
\hline Dyspnea & & 6 & & & 3 & 3 & 0 \\
\hline Fatigue & & 9 & & & 3 & 6 & 5 \\
\hline Pharyngeal pain & & 6 & & & 2 & 4 & 3 \\
\hline Eczema & & & 9 & 6 & & & \\
\hline Nausea & & & 9 & 2 & & & \\
\hline Paronychia & & & 9 & 1 & & & \\
\hline Vertebral compression fracture & & & 3 & 3 & & & \\
\hline Any gastrointestinal disorder ${ }^{a}$ & & 37 & 21 & 18 & 63 & 68 & 55 \\
\hline Mouth ulcers & & & & & 4 & 5 & I \\
\hline Peptic ulcers & & & & & 1 & 0 & 2 \\
\hline Peripheral edema & & & & & 5 & 4 & 2 \\
\hline Pyrexia & & & & & 2 & I & 5 \\
\hline
\end{tabular}

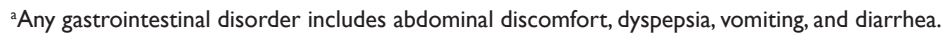

the carotid artery in patients with moderate to high prevalence of CAD. ${ }^{42}$ IL- 6 was evaluated in patients undergoing coronary artery bypass grafting, and elevated preoperative IL-6 levels were predictors of both early graft occlusion and late cardiovascular events after surgery. ${ }^{43}$ Furthermore, high plasma levels of IL-6 were an independent predictor of stroke in patients with atrial fibrillation. ${ }^{44}$

CAD is a major cause of death in patients with RA, and it is possible that IL- 6 could contribute to the excess burden of cardiovascular disease in RA patients. While tocilizumab treatment was frequently associated with elevated total cholesterol and LDL in the above studies, and improvement in HDL was also seen in some patients, and the ApoB/ApoA atherogenic index was generally unchanged. At this point in time, it is unclear what the impact of these changes will be upon overall cardiovascular risk in RA patients treated with tocilizumab.

\section{Conclusion}

IL-6 is a major inflammatory cytokine that contributes to the pathophysiology of RA, and IL-6 blockade is beneficial in experimental animal models of inflammatory arthritis. Clinical trial data have shown tocilizumab to be efficacious in moderate to severe rheumatoid patients failing DMARDS and anti-TNF agents. Given the promising results of tocilizumab in the treatment of RA, inhibition of IL-6 signaling with tocilizumab could be beneficial in other autoimmune diseases where IL-6 plays a role in the inflammatory cascade.

Cardiovascular disease is an important outcome in RA. The long term impact of tocilizumab on overall cardiovascular risk in RA patients remains unclear; however the influence of tocilizumab upon atherosclerotic disease is an important area for future exploration.

The toxicity associated with the long term use of tocilizumab is unknown. It is possible that adverse events could 
be prevented with proper patient selection in the future as we develop a more individualized approach to patient care. In the future, a team approach aiming to provide comprehensive clinical, translational, and economic research will allow us to serve our patients best.

\section{Disclosures}

The authors declare no conflicts of interest.

\section{References}

1. Helmick CG, Felson DT, Lawrence RC, et al. Estimates of the prevalence of arthritis and other rheumatic conditions in the United States. Part I. Arthritis Rheum. 2008;58:15-25.

2. Arthritis F. Rheumatoid arthritis fact sheet. 2009. http://www.arthritis. org/media/newsroom/media-kits/Rheumatoid_Arthritis_Fact_Sheet.pdf

3. Olivieri I, Palazzi C, Peruz G, Padula A. Management issues with elderly-onset rheumatoid arthritis: an update. Drugs Aging. 2005;22:809-822.

4. Jackson CG, Williams HJ. Disease-modifying antirheumatic drugs. Using their clinical pharmacological effects as a guide to their selection. Drugs. 1998;56:337-344.

5. Nurmohamed MT, Dijkmans BA. Efficacy, tolerability and cost effectiveness of disease-modifying antirheumatic drugs and biologic agents in rheumatoid arthritis. Drugs. 2005;65:661-694.

6. Choy EH, Panayi GS. Cytokine pathways and joint inflammation in rheumatoid arthritis. N Engl J Med. 2001;344:907-916.

7. Van Snick J. Interleukin-6: an overview. Annu Rev Immunol. 1990;8:253-278.

8. Genovese MC, Kaine JL, Lowenstein MB, et al. Ocrelizumab, a humanized anti-CD20 monoclonal antibody, in the treatment of patients with rheumatoid arthritis: A phase I/II randomized, blinded, placebocontrolled, dose-ranging study. Arthritis Rheum. 2008;58:2652-2661.

9. Hirano T, Matsuda T, Turner M, et al. Excessive production of interleukin 6/B cell stimulatory factor-2 in rheumatoid arthritis. Eur J Immunol. 1988;18:1797-1801.

10. Agency EM. RoActemra (Tocilizumab: summary of product characteristics): summary of product characteristics. 2009.

11. A proposed revision to the ACR20: the hybrid measure of American College of Rheumatology response. Arthritis Rheum. 2007;57: 193-202.

12. McInnes IB, Schett G. Cytokines in the pathogenesis of rheumatoid arthritis. Nat Rev Immunol. 2007;7:429-442.

13. Nielen MM, van Schaardenburg D, Reesink HW, et al. Simultaneous development of acute phase response and autoantibodies in preclinical rheumatoid arthritis. Ann Rheum Dis. 2006;65:535-537.

14. Niewold TB, Harrison MJ, Paget SA. Anti-CCP antibody testing as a diagnostic and prognostic tool in rheumatoid arthritis. QJM. 2007;100:193-201.

15. Lally F, Smith E, Filer A, et al. A novel mechanism of neutrophil recruitment in a coculture model of the rheumatoid synovium. Arthritis Rheum. 2005;52:3460-3469.

16. Romano M, Sironi M, Toniatti C, et al. Role of IL-6 and its soluble receptor in induction of chemokines and leukocyte recruitment. Immunity. 1997;6:315-325.

17. Kaplanski G, Marin V, Montero-Julian F, Mantovani A, Farnarier C. IL-6: a regulator of the transition from neutrophil to monocyte recruitment during inflammation. Trends Immunol. 2003;24:25-29.

18. Mihara M, Kasutani K, Okazaki M, et al. Tocilizumab inhibits signal transduction mediated by both mIL-6R and sIL-6R, but not by the receptors of other members of IL-6 cytokine family. Int Immunopharmacol. 2005;5:1731-1740.

19. Sack U, Kinne RW, Marx T, Heppt P, Bender S, Emmrich, F. Interleukin-6 in synovial fluid is closely associated with chronic synovitis in rheumatoid arthritis. Rheumaltology Int. 1993;13:45-51.
20. Streetz KL, Tacke F, Leifeld L, et al. Interleukin 6/gp130-dependent pathways are protective during chronic liver diseases. Hepatology. 2003:38:218-229.

21. Castell JV, Gomez-Lechon MJ, David M, et al. Interleukin-6 is the major regulator of acute phase protein synthesis in adult human hepatocytes. FEBS Lett. 1989;242:237-239.

22. Gauldie J, Sauder DN, McAdam KP, Dinarello CA. Purified interleukin1 (IL-1) from human monocytes stimulates acute-phase protein synthesis by rodent hepatocytes in vitro. Immunology. 1987;60:203-207.

23. Ridker PM, Cook N. Clinical usefulness of very high and very low levels of C-reactive protein across the full range of Framingham Risk Scores. Circulation. 2004;109:1955-1959.

24. Ridker PM, Rifai N, Stampfer MJ, Hennekens CH. Plasma concentration of interleukin- 6 and the risk of future myocardial infarction among apparently healthy men. Circulation. 2000;101:1767-1772.

25. Biasucci LM, Liuzzo G, Fantuzzi G, et al. Increasing levels of interleukin (IL)-1Ra and IL-6 during the first 2 days of hospitalization in unstable angina are associated with increased risk of in-hospital coronary events. Circulation. 1999;99:2079-2084.

26. Nishimoto N, Kishimoto T. Humanized antihuman IL-6 receptor antibody, tocilizumab. Handb Exp Pharmacol. 2008:151-160.

27. Hibi M, Murakami M, Saito M, Hirano T, Taga T, Kishimoto T. Molecular cloning and expression of an IL-6 signal transducer, gp130. Cell. 1990;63:1149-1157.

28. Choy EH, Isenberg DA, Garrood T, et al. Therapeutic benefit of blocking interleukin-6 activity with an anti-interleukin-6 receptor monoclonal antibody in rheumatoid arthritis: a randomized, doubleblind, placebo-controlled, dose-escalation trial. Arthritis Rheum. 2002;46:3143-3150.

29. Maini RN, Taylor PC, Szechinski J, et al. Double-blind randomized controlled clinical trial of the interleukin- 6 receptor antagonist, tocilizumab, in European patients with rheumatoid arthritis who had an incomplete response to methotrexate. Arthritis Rheum. 2006;54: 2817-2829.

30. Fleishman R. Tocilizumab inhibits radiographic progression and improves physical function in rheumatoid arthritis patients at 2 years with increasing clinical efficacy over time. Proceedings ACR, Philadelphia, PA Oct 18, 2009.

31. Nishimoto N, Hashimoto J, Miyasaka N, et al. Study of active controlled monotherapy used for rheumatoid arthritis, an IL-6 inhibitor (SAMURAI): evidence of clinical and radiographic benefit from an x-ray reader-blinded randomised controlled trial of tocilizumab. Ann Rheum Dis. 2007;66:1162-1167.

32. Nishimoto N, Miyasaka N, Yamamoto K, et al. Study of active controlled tocilizumab monotherapy for rheumatoid arthritis patients with an inadequate response to methotrexate (SATORI): significant reduction in disease activity and serum vascular endothelial growth factor by IL-6 receptor inhibition therapy. Mod Rheumatol. 2009;19:12-19.

33. Smolen JS, Beaulieu A, Rubbert-Roth A, et al. Effect of interleukin-6 receptor inhibition with tocilizumab in patients with rheumatoid arthritis (OPTION study): a double-blind, placebo-controlled, randomised trial. Lancet. 2008;371:987-997.

34. Emery P, Keystone E, Tony HP, et al. IL-6 receptor inhibition with tocilizumab improves treatment outcomes in patients with rheumatoid arthritis refractory to anti-tumour necrosis factor biologicals: results from a 24-week multicentre randomised placebo-controlled trial. Ann Rheum Dis. 2008;67:1516-1523.

35. Genovese MC, McKay JD, Nasonov EL, et al. Interleukin-6 receptor inhibition with tocilizumab reduces disease activity in rheumatoidarthritis with inadequate response to disease-modifying antirheumatic drugs: the tocilizumab in combination with traditional diseasemodifying antirheumatic drug therapy study. Arthritis Rheum. 2008;58: 2968-2980.

36. Jones G, Sebba A, Gu J, et al. Comparison of tocilizumab monotherapy versus methotrexate monotherapy in patients with moderate to severe rheumatoid arthritis: The AMBITION study. Ann Rheum Dis. 2010;69:88-96. 
37. Nishimoto N, Yoshizaki K, Miyasaka N, et al. Treatment of rheumatoid arthritis with humanized anti-interleukin-6 receptor antibody: a multicenter, double-blind, placebo-controlled trial. Arthritis Rheum. 2004;50:1761-1769.

38. Emery P, Fleischmann R, Filipowicz-Sosnowska A, et al. The efficacy and safety of rituximab in patients with active rheumatoid arthritis despite methotrexate treatment: results of a phase IIB randomized, double-blind, placebo-controlled, dose-ranging trial. Arthritis Rheum. 2006;54:1390-1400.

39. Smolen JS, Han C, van der Heijde DM, et al. Radiographic changes in rheumatoid arthritis patients attaining different disease activity states with methotrexate monotherapy and infliximab plus methotrexate: the impacts of remission and tumour necrosis factor blockade. Ann Rheum Dis. 2009;68:823-827.

40. Kanda J, Kawabata H, Yamaji Y, et al. Reversible cardiomyopathy associated with Multicentric Castleman disease: successful treatment with tocilizumab, an anti-interleukin 6 receptor antibody. Int J Hematol. 2007;85:207-211.
41. Hoffmeister A, Rothenbacher D, Kunze M, Brenner H, Koenig W. Prognostic value of inflammatory markers alone and in combination with blood lipids in patients with stable coronary artery disease. Eur J Intern Med. 2005;16:47-52.

42. Larsson PT, Hallerstam S, Rosfors S, Wallen NH. Circulating markers of inflammation are related to carotid artery atherosclerosis. Int Angiol. 2005;24:43-51.

43. Hedman A, Larsson, Thomas $\mathrm{P}$, et al. Do preoperative inflammatory parameters predict early graft occlusion and late cardiovascular events? Cat Ins. 2007.

44. Conway DS, Buggins P, Hughes E, Lip GY. Prognostic significance of raised plasma levels of interleukin-6 and C-reactive protein in atrial fibrillation. Am Heart J. 2004;148:462-466.

45. Bhatt DL, Fox KA, Hacke W, et al. Clopidogrel and aspirin versus aspirin alone for the prevention of atherothrombotic events. $N$ Engl J Med. 2006;354:1706-1717.
Therapeutics and Clinical Risk Management

\section{Publish your work in this journal}

Therapeutics and Clinical Risk Management is an international, peerreviewed journal of clinical therapeutics and risk management, focusing on concise rapid reporting of clinical studies in all therapeutic areas, outcomes, safety, and programs for the effective, safe, and sustained use of medicines. This journal is indexed on PubMed Central, CAS,

\section{Dovepress}

EMBase, Scopus and the Elsevier Bibliographic databases. The manuscript management system is completely online and includes a very quick and fair peer-review system, which is all easy to use. Visit http://www.dovepress.com/testimonials.php to read real quotes from published authors.

Submit your manuscript here: http://www.dovepress.com/therapeutics-and-clinical-risk-management-journal 